\title{
Corrosion Behaviour of High Chromium White Iron Hardfacing Alloys in Acidic and Neutral Solutions
}

\author{
Varmaa Marimuthu $^{1}$ (D) Krishnan Kannoorpatti ${ }^{1}$
}

Received: 9 August 2016/Revised: 3 October 2016/Accepted: 5 October 2016/Published online: 11 October 2016

(C) Springer International Publishing Switzerland 2016

\begin{abstract}
Hardfacing alloys of High Chromium White Irons (HCWI) were deposited on low carbon steel using Shielded Metal Arc Welding. Microstructure of HCWI consists of primary carbides, eutectic carbides and eutectic austenitic/martensitic matrix. This study investigated the corrosion behaviour of HCWI in both acid and neutral solutions. The corrosion behaviour of HCWI was evaluated using anodic polarisation technique. It was found that in acid solution at $\mathrm{pH} 1.5$, corrosion occurs on eutectic austenite/martensitic matrix whereas at $\mathrm{pH} 2$, the corrosion occurs on eutectic carbides. In the neutral environment at $\mathrm{pH} 7$, corrosion of HCWI occurred in the eutectic austenite/martensite matrix in the presence of chloride ions, while in the buffered solution, corrosion occurred in the carbides. The results of this study show that the corrosion mechanism of HCWI for both acid and neutral environments was due to potential difference between carbides and eutectic austenite/martensitic matrix. The superimposed Pourbaix diagrams of chromium carbides with iron $(\mathrm{Fe})$ and niobium carbide were useful in explaining the behaviour of HCWI in both acid and neutral solutions.
\end{abstract}

Keywords Hardfacing - High chromium white irons . Acid $\cdot$ Neutral $\cdot$ Chloride ions $\cdot$ Pourbaix diagram of carbides

Varmaa Marimuthu

varmaa.marimuthu@cdu.edu.au

1 School of Engineering and IT, Charles Darwin University, Darwin, Australia

\section{Introduction}

The excellent abrasion and wear-resistant High Chromium White Irons (HCWI) hardfacing alloys used in sugarcane rolls, pump impeller components, oil and gas pipelines and also to rebuild screw barrels in plastic industry are exposed to strong acidic environment and there are limited studies on the corrosion behaviour of hardfacing alloys [1-4]. HCWI components for crushing and grinding mill liners, deep-sea drilling operations, seawater valves and subsea oil operations are exposed to neutral and seawater environment $[5,6]$. Investigation done by Rogers [7] on corrosion of hardfacing alloys in marine environment showed that corrosion occurred in the chromium-depleted region of the austenite matrix while forming chromium carbides. This type of corrosion was also found in valves depending on the exposed time under seawater. Galvanic couple is formed between the carbide and matrix, where chromiumdepleted austenite matrix acts as an anode and carbide acts as a cathode in seawater environment.

Similarly, the studies conducted for HCWI in acidic $[1,8-13]$ and neutral $[8,14-19]$ environments proposed that preferential corrosion of eutectic austenite or martensitic matrix occurred due to the formation of galvanic cell between carbides and eutectic austenite or martensite matrix. Zhang et al. [13] conducted experiment at $\mathrm{pH} 1.5$ acidic solution by separating carbides and eutectic austenite matrix from HCWI hardfacing alloys. It was found that corrosion occurs mainly due to potential difference between eutectic austenite matrix and carbides. In pH 1.5 solution, carbides attained more noble potential than eutectic austenite matrix. Other investigators $[8,11,17,20-22]$ proposed that HCWI corrosion occurred at interface between carbides and eutectic austenite matrix for both acidic and neutral environments. They also suggested that the cause of corrosion 
was due to the depletion of chromium below $12 \%$ at interfaces while forming carbides, which hindered the formation of passive film.

Aziz et al. [8] found that corrosion was strongly dependent upon the corrosive environment, and the evolution of hydrogen in acidic medium prevented the formation of passive film on HCWI surface. Tang et al. [9, 10] found that in acidic solution of $0.5 \mathrm{M} \mathrm{H}_{2} \mathrm{SO}_{4}$, the corrosion rate decreased with increasing percentage of carbon which resulted in HCWI to form more chromium carbides which decreases the volume fraction of austenite matrix. The higher carbon content increased the area ratio of cathode chromium carbides to anode eutectic austenite matrix in acidic environment.

Only limited studies [23, 24] suggested the effect of chloride ions in the microstructure of HCWI. It was proposed that chloride ions did not allow the eutectic austenite matrix to form a passive film on the surface. Tian et al. [11] found that due to diffusion control of chloride ions, the corrosion rate of HCWI was significantly lesser for higher chloride concentration than lower chloride concentration. Tang et al. [9] showed that the volume loss of HCWI was significantly higher at neutral $\mathrm{pH} 7$ than at $\mathrm{pH} 3$ and 5. It was due to the formation of weakened passive layer of HCWI in neutral solution.

Despite the significant findings on corrosion behaviour of HCWI, many authors did not discuss a method to predict corrosion behaviour. This is where the application of Pourbaix or E-pH diagrams fits in. There are only limited studies in the use of Pourbaix diagrams to predict a trend for the corrosion behaviour of hardfacing alloys in both acidic and neutral environments. Pourbaix diagrams can not only be used to predict the corrosion behaviour of materials, but also provide a simplified explanation of complicated chemistry and thermodynamics. Pourbaix diagrams can also be used to diagnose past and present problems in a thoughtful manner. They can also be used to design suitable experiments in an electrolyte of interest. Some investigators have used the Pourbaix diagrams of metals to explain the behaviour of corrosion of metals in natural sea water and aqueous sulfidic solution [25, 26]. With this in view, Varmaa et al. [27, 28] developed Pourbaix diagrams for carbides in order to explain the trend observed in the corrosion behaviour of carbides. In this experimental study, the corrosion of hardfacing alloys based on HCWI, in acidic and neutral environments, will be explained through the use of Pourbaix diagrams of carbides.

\section{Experimental Procedure}

Hardfacing alloys based on HCWI were deposited on low carbon steel using shielded metal arc welding. The typical compositions of the deposited hardfacing alloys are given in Table 1. Alloy 1 with boron element mainly forms eutectic martensitic matrix along with chromium carbides, while Alloy 2 had a number of elements, such as niobium, molybdenum, and tungsten forms complex carbides with eutectic austenite matrix [29, 30]. These elements would form carbides in preference to chromium, and hence this sample was likely to contain complex carbides. The recommended welding parameters provided by the manufacturer of the hardfacing alloys are given in Table 2. To avoid dilution, welding was performed in four layers. Samples cut from the weld deposits were prepared for microstructural observations. The samples were etched in $20 \mathrm{ml}$ distilled water, $10 \mathrm{ml} \mathrm{HCl}, 30 \mathrm{ml} \mathrm{HNO}_{3}$, and $5 \mathrm{~g}$ of $\mathrm{FeCl}_{3}$ [31].

Corrosion tests were conducted using electrochemical methods with a Gamry Reference 3000 potentiostat and a three-electrode cell. The HCWI (sample area $=2.85 \mathrm{~cm}^{2}$ ) was the working electrode exposed to electrolytes with selected $\mathrm{pH}$, as shown in Table 3. $\mathrm{pH} \mathrm{1.5,2}$ and 7 were selected for explaining the trend of corrosion behaviour of HCWI in different regions of Pourbaix diagram of carbides [27, 28]. Solutions with $\mathrm{pH} 1.5$ and 2 were prepared from diluting sulphuric acid with distilled water. The effect of chloride ions was analysed in $\mathrm{pH} 7 \mathrm{NaCl}$ solution. The graphite and silver/silver chloride were the counter and reference electrodes respectively. Before measuring corrosion potential, the electrolyte in the corrosion cell was deaerated using nitrogen gas for $30 \mathrm{~min}$ as described in the ASTM Standard G5-94 [32]. The open-circuit potential (Ecorr) was measured after $10 \mathrm{~min}$, and then the potentiodynamic test was conducted at a scan rate of $0.17 \mathrm{mV} / \mathrm{s}$ [14]. The potentiodynamic test was continued till the sample reached the final potential $2 \mathrm{~V}$. The final potential $2 \mathrm{~V}$ was selected on the basis of maximum potential used in the Pourbaix diagram of carbides [27, 28]. Then the microstructure was examined using an optical microscope by removing the corrosion product using rubber cork under running tap water [2]. The sample weight and $\mathrm{pH}$ of electrolyte were measured before and after corrosion test for identifying the changes that happened during the potentiodynamic test.

The hardness was measured before and after corrosion test on HCWI samples using Vickers hardness testing machine at $10 \mathrm{~g}$ load. The $10 \mathrm{~g}$ load was chosen to measure the hardness of carbides and eutectic austenite/martensitic matrix separately. The Scanning Electron Microscopy (SEM, Philips XL 30 series) was used to study the microstructure and Energy Dispersive X-ray Spectrometry (EDS) was used to study the chemical composition of the microstructural phases. The Inductively Coupled Plasma Mass Spectrometry (ICPMS) was used to analyse the chemical composition of the electrolyte after the corrosion tests. Sample with higher dissolved solids was analysed 
Table 1 Typical Chemical compositions (wt \%) of hardfacing alloys

\begin{tabular}{llllllllllll}
\hline Alloy type & $\mathrm{C}$ & $\mathrm{Cr}$ & $\mathrm{Mn}$ & $\mathrm{V}$ & $\mathrm{Si}$ & $\mathrm{B}$ & $\mathrm{Ni}$ & $\mathrm{Mo}$ & $\mathrm{W}$ & $\mathrm{Nb}$ & $\mathrm{Fe}$ \\
\hline Alloy 1 & 3.2 & 24 & 0.4 & 1.7 & 2.4 & 1.2 & - & - & - & - & Bal. \\
Alloy 2 & 4.2 & 22.6 & 0.2 & 1.7 & 2.0 & - & - & 5.8 & 2.2 & 5.0 & Bal. \\
\hline
\end{tabular}

Table 2 Welding Parameters

\begin{tabular}{lllll}
\hline Welding type & Welding voltage $(\mathrm{V})$ & Welding current $(\mathrm{A})$ & Welding speed $(\mathrm{mm} / \mathrm{min})$ & Depositing numbers \\
\hline MMAW & 32 & $100-150$ & $120-200$ & 4 layers, 5 beads \\
\hline
\end{tabular}

Table 3 Composition of electrolytes for anodic polarisation tests

\begin{tabular}{llc}
\hline Samples & Electrolyte & $\mathrm{pH}$ \\
\hline Alloy 1 & diluted $\mathrm{H}_{2} \mathrm{SO}_{4}$ & 1.5 \\
Alloy 2 & diluted $\mathrm{H}_{2} \mathrm{SO}_{4}$ & 2 \\
Alloy 1 & $2 \mathrm{M} \mathrm{NaCl}$ & 7 \\
Alloy 2 & Buffer solution (containing potassium dihdrogen phosphate, sodium phosphate dibasic, preservative and dye) & 7 \\
\hline
\end{tabular}

using Inductively Coupled Plasma Optical Emission Spectrometry (ICPOES).

\section{Results}

\subsection{Microstructure Characteristics of HCWI Alloys}

Figure 1 shows the microstructure of alloy 1 hardfacing sample. The microstructure shows primary carbides surrounded by eutectic carbides and martensite. The boron content present in alloy 1 helps to alter the eutectic matrix from austenite to martensitic [29, 30]. The primary carbides were polygonal and some needle shaped depending on the direction of solidification. The primary and eutectic carbides are of the type $\mathrm{M}_{7} \mathrm{C}_{3}$ and $\mathrm{M}_{23} \mathrm{C}_{6}$, respectively. The $\mathrm{M}_{7} \mathrm{C}_{3}$ carbides were considered to be more stable than $\mathrm{M}_{23} \mathrm{C}_{6}$ carbides [15, 33-38]. Figure 2 shows the microstructure of alloy 2 sample. The microstructure shows again primary carbides surrounded by eutectic carbides and austenite. The microstructure also shows some light regions of niobium carbide ( $\mathrm{NbC}$ ) [35]. The niobium element in alloy 2 helps to enrich the chromium in matrix which increases the austenite formation temperature and forms austenite matrix. The formation of reinforced $\mathrm{NbC}$ in alloy 2 helps prevent the detachment of chromium-rich $\mathrm{M}_{7} \mathrm{C}_{3}$ primary carbides $[35,39]$.

The SEM pictures of the alloy 1 and alloy 2 samples are given in Fig. 3i, ii. The point elemental analysis was done on primary carbides (a), carbide/matrix interfaces (b),

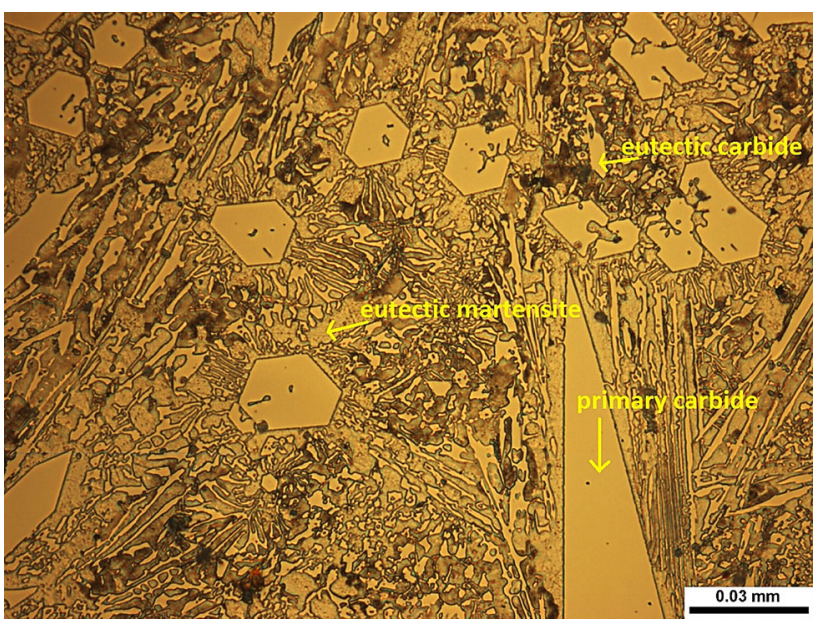

Fig. 1 Microstructure of alloy 1 sample showing polygonal primary carbides surrounded by eutectic carbides and martensite

matrix (c) and eutectic carbides (d) and the values are given in Table 4. In Fig. 3ii, the area marked d1 was found to be molybdenum carbide. In Fig. 3ii, the area marked a1 was found to be $\mathrm{NbC}$. From Table 4, it can be seen that the primary and eutectic carbides (a and d, respectively) had high amounts of chromium in both the samples. Area b and c denote the carbide-austenite interface, and eutectic austenite or martensite matrix shows that the chromium is lower than primary carbides but higher amount of iron present in both the samples. The results of Table 4 show that larger amount of chromium was consumed while forming primary and eutectic carbides. 


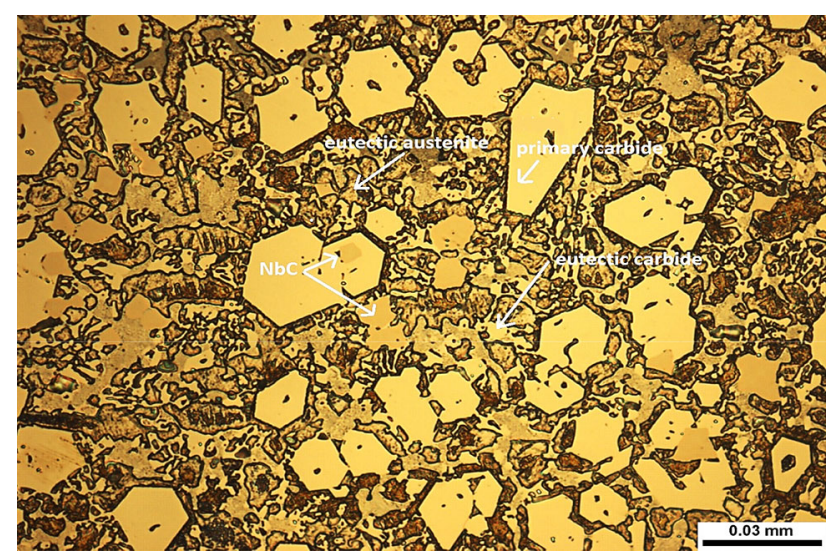

Fig. 2 Microstructure of alloy 2 sample showing polygonal primary carbides surrounded by eutectic carbides and austenite. Light regions are $\mathrm{NbCs}$
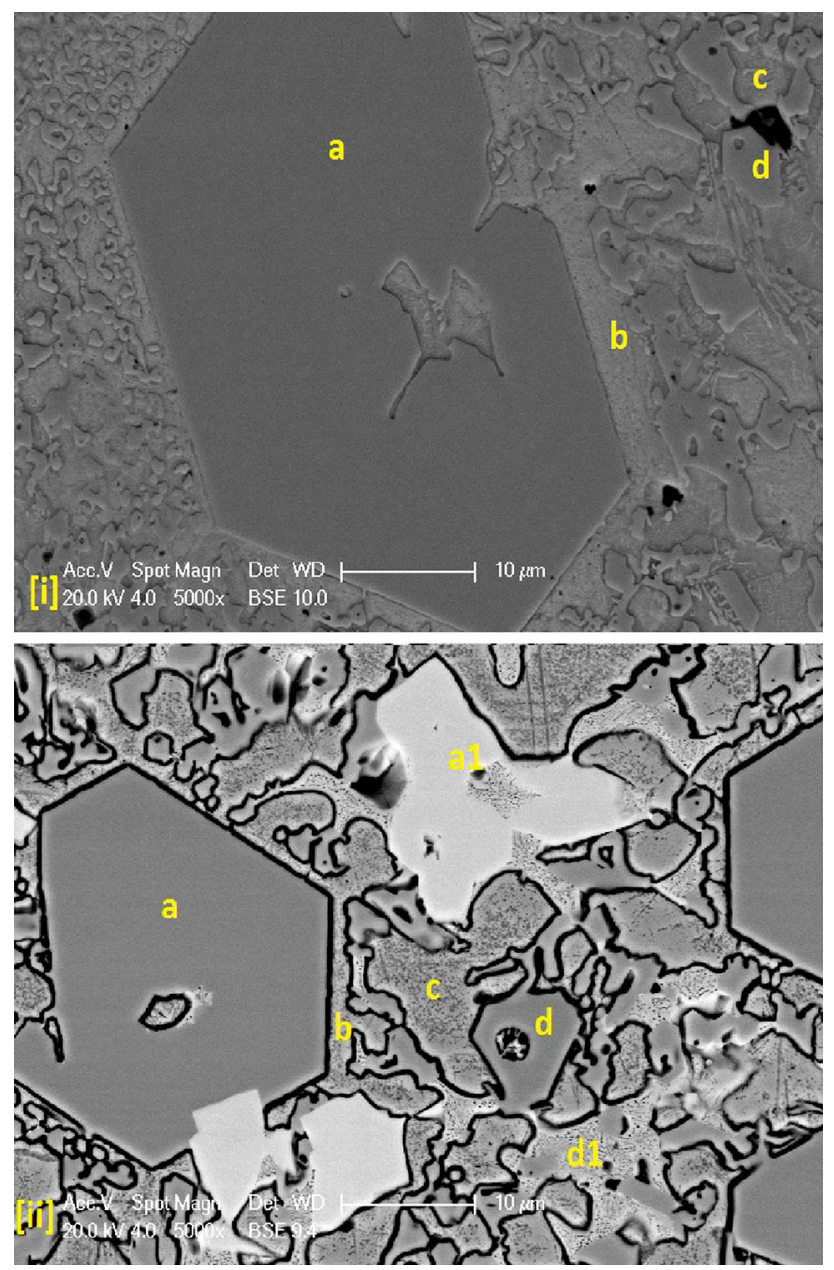

Fig. 3 SEM analysis of $i$ alloy 1 and $i i$ alloy 2 hardfacing samples

The hardness of carbide and matrix for both alloy 1 and 2 samples was measured with $10 \mathrm{~g}$ load, as shown in Table 5. The hardness of carbide and eutectic martensitic
Table 4 EDS analysis (wt\%) for hardfacing samples

\begin{tabular}{lllll}
\hline Samples & $\mathrm{Cr}$ & $\mathrm{Fe}$ & $\mathrm{Nb}$ & $\mathrm{Mo}$ \\
\hline Alloy 1 & & & & \\
a & 42.48 & 32.85 & - & - \\
$\mathrm{b}$ & 15.04 & 66.87 & - & - \\
$\mathrm{c}$ & 13.46 & 75.54 & - & - \\
d & 30.33 & 52.29 & - & - \\
a & 49.93 & 24.55 & - & - \\
Alloy 2 & & & & \\
a1 & - & - & 65.75 & - \\
b & 14.38 & 68.95 & - & - \\
c & 13.07 & 79.48 & - & - \\
d & 53.99 & 33.96 & - & - \\
d1 & 20.52 & 56.33 & - & 17.39 \\
\hline
\end{tabular}

Where $a$ primary carbides; $b$ carbide/matrix interface; $c$ matrix; $d, d 1$ eutectic carbides

matrix for alloy 1 sample found to be higher than the alloy 2 sample. This may be due to addition of boron content which significantly increases the hardness of the microstructure of alloy 1 . According to previous studies [22, 40], eutectic martensitic matrix of alloy 1 sample found to be harder than the eutectic austenite matrix of alloy 2 sample.

\subsection{Corrosion Behaviour of HCWI Alloys}

\subsubsection{Potentiodynamic Tests}

The potentiodynamic tests were conducted by exposing the HCWI samples to the selected electrolytes of $\mathrm{pH} 1.5,2$ and 7. The Rest Potential (RP) changes with the nature of electrolyte and $\mathrm{pH}$ for both the samples, alloy 1 and 2 . In Fig. 4, the potentiodynamic curve of alloy 1 in $\mathrm{H}_{2} \mathrm{SO}_{4}$ of pH 1.5 exhibits an active behaviour rather than activepassive behaviour. The pitting can be noted on the curve especially at higher potentials. Figure 5 shows the microstructure of alloy 1 sample at Final Potential (FP) of the potentiodynamic curve in Fig. 4. It can be seen that the dissolution of eutectic martensitic matrix occurred in preference to carbides. The primary and eutectic carbides were seen to be protected from corrosion at FP in $\mathrm{pH} 1.5$ solution. The potentiodynamic curve of alloy 2 in $\mathrm{H}_{2} \mathrm{SO}_{4}$ of pH 2 shows active-passive behaviour as shown in Fig. 6 . The active behaviour of alloy 2 starts from RP until point 1 , after that passive behaviour of alloy 2 was seen from points 1 to 2 and then trans-passive region was observed from point 2 to FP. The microstructure of alloy 2 sample in Fig. 7 shows that the corrosion occurs in the eutectic 
Table 5 Hardness of carbide and matrix of Alloy 1 and 2

\begin{tabular}{lll}
\hline Samples & Carbide (HV) & Eutectic austenitic or martensitic matrix (HV) \\
\hline Alloy 1 & 2015 & 835 \\
Alloy 2 & 1711 & 420 \\
\hline
\end{tabular}

Alloy 1

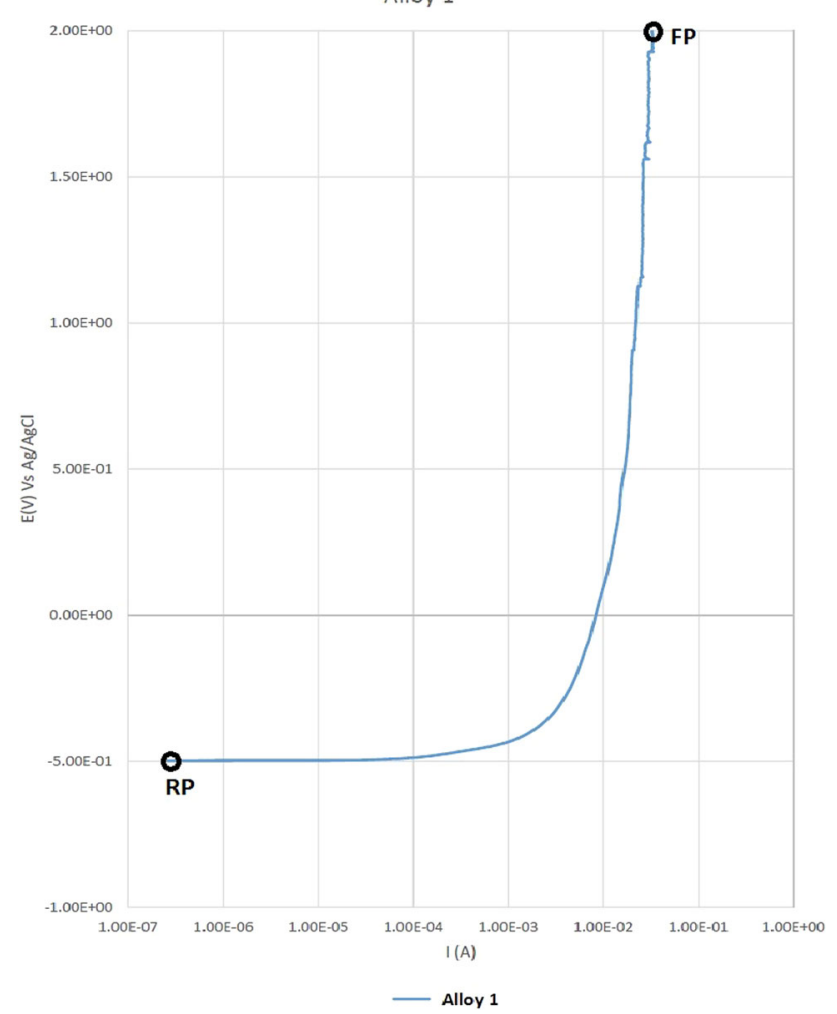

Fig. 4 Anodic polarisation curve for alloy 1 in $\mathrm{pH} 1.5$ solution

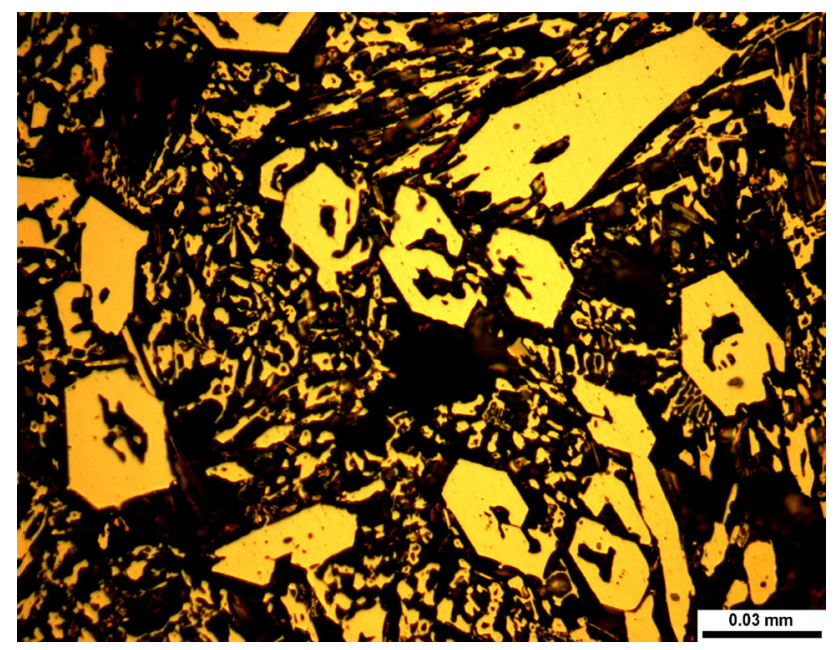

Fig. 5 Microstructure of corroded eutectic martensitic matrix of Alloy 1 after anodic polarisation test in $\mathrm{pH} 1.5$ solution

carbides rather than the eutectic austenite matrix at FP of Fig. 6. The niobium and primary carbides were seen to be uncorroded at FP in $\mathrm{pH} 2$ solution.

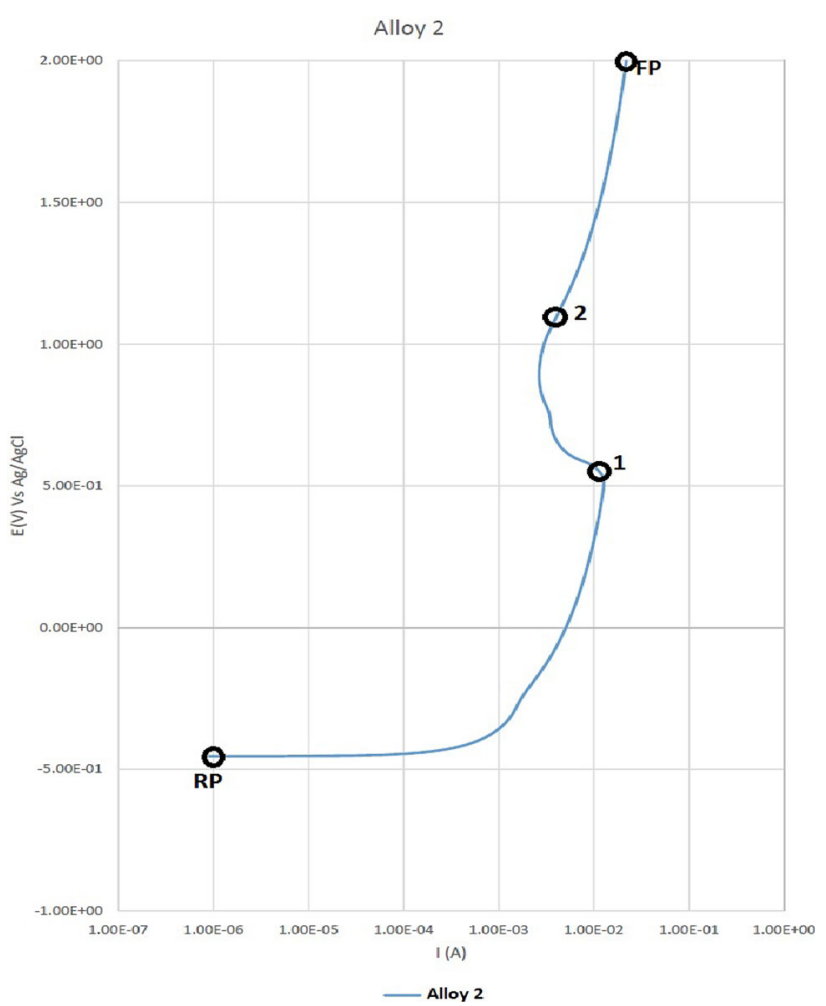

Fig. 6 Anodic polarisation curve for alloy 2 in $\mathrm{pH} 2$ solution

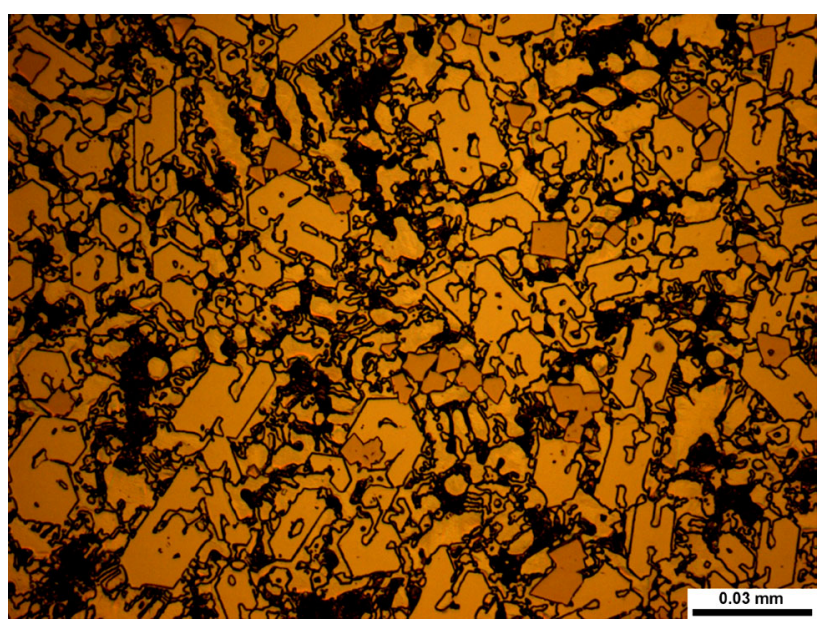

Fig. 7 Microstructure of corroded eutectic carbides of Alloy 2 after anodic polarisation test in $\mathrm{pH} 2$ solution

In neutral solution at $\mathrm{pH} 7$, Fig. 8 shows the potentiodynamic curve of alloy 1 at $2 \mathrm{M} \mathrm{NaCl}$ solution which exhibits active and slight passive behaviour from RP to FP. 
The presence of aggressive chloride ions in the solution does not allow the formation of passive film on the surface of HCWI. The microstructure of alloy 1 in Fig. 9 shows complete dissolution of eutectic martensitic matrix by protecting eutectic and primary carbides at FP of Fig. 8. In pH 7 buffer solution, Fig. 10 of alloy 2 shows passivetranspassive behaviour. The passive behaviour of alloy 2 in buffer solution starts from RP until point 1 and then the transpassive behaviour was observed from point 1 to FP. Figure 11 shows the microstructure of alloy 2 sample at FP of the potentiodynamic curve in Fig. 10. It can be seen that dissolution of eutectic and primary carbides with preference to eutectic austenite matrix. The $\mathrm{NbCs}$ were seen to be uncorroded at FP in $\mathrm{pH} 7$ buffer solution.

In summary, it can be said that in alloy $1 \mathrm{H}_{2} \mathrm{SO}_{4}$ of $\mathrm{pH}$ 1.5 and in $2 \mathrm{M} \mathrm{NaCl}$ solution of $\mathrm{pH} 7$, eutectic martensitic matrix has dissolved completely leaving eutectic and primary carbides with little corrosion, whereas, by exposing alloy 2 to $\mathrm{H}_{2} \mathrm{SO}_{4}$ solution of $\mathrm{pH} 2$, eutectic carbide gets corroded in preference to eutectic austenite matrix. In addition to that alloy 2 at $\mathrm{pH} 7$ of buffer solution, eutectic and primary carbides get corroded in preference to eutectic austenite and $\mathrm{NbCs.}$

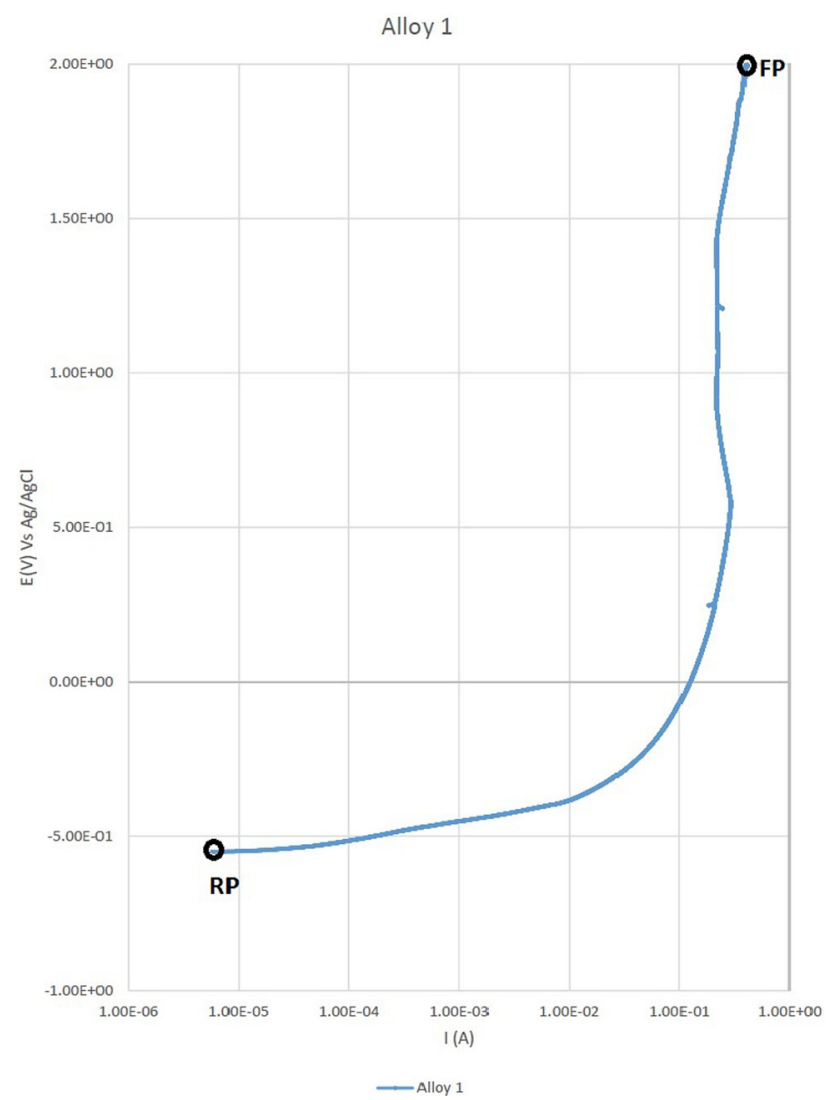

Fig. 8 Anodic polarisation curve for alloy 1 in $\mathrm{pH} 72 \mathrm{MNaCl}$ solution

\subsubsection{HCWI Samples and Electrolyte Analysis After Corrosion}

The values for RP and corrosion current (Icorr) at FP of potentiodynamic curves for HCWI samples for selected

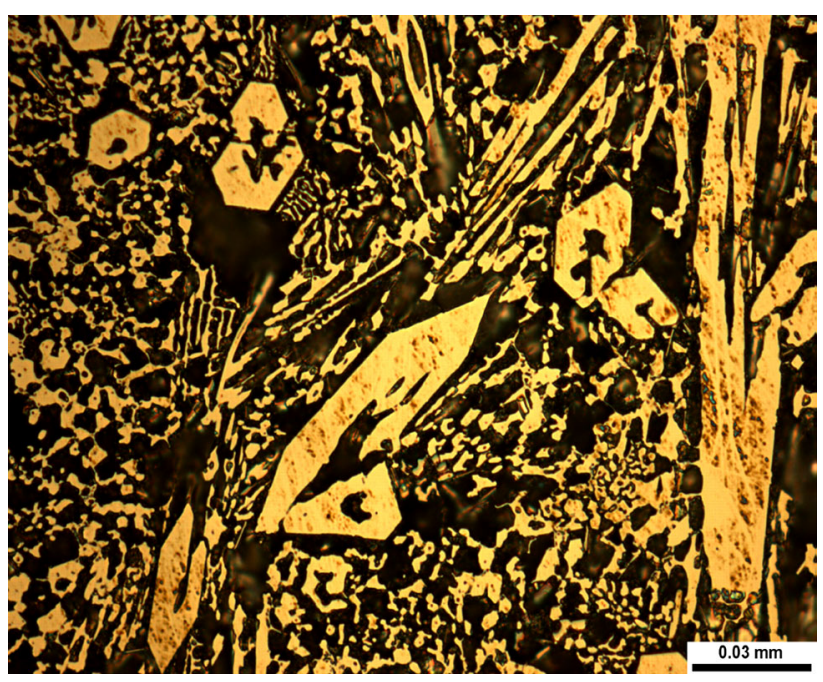

Fig. 9 Microstructure of corroded eutectic martensitic matrix of Alloy 1 after anodic polarisation test in $\mathrm{pH} 7 \mathrm{NaCl}$ solution

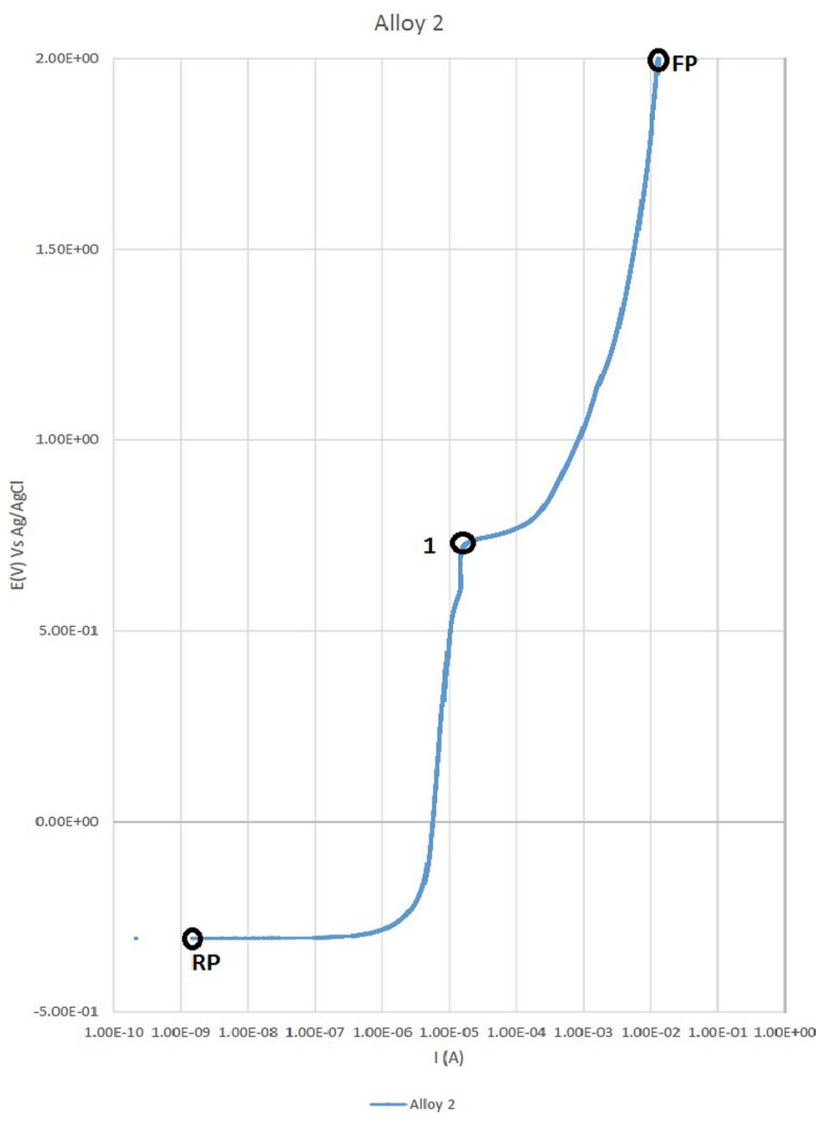

Fig. 10 Anodic polarisation curve for alloy 2 in $\mathrm{pH} 7$ buffer solution 


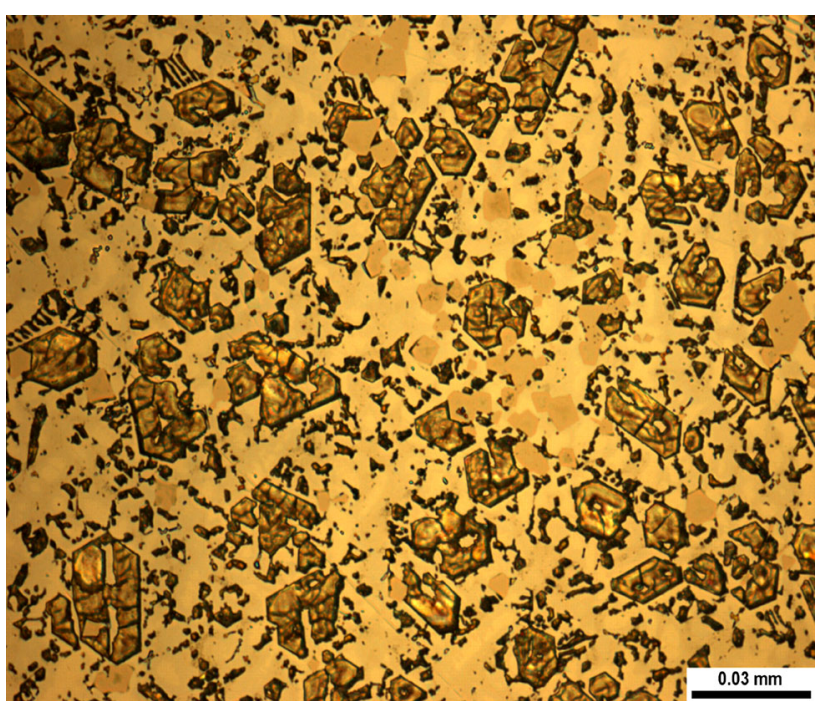

Fig. 11 Microstructure of corroded primary and eutectic carbides of Alloy 2 after anodic polarisation test in $\mathrm{pH} 7$ buffer solution

environments are given in Table 6. Samples in $\mathrm{pH} 7$ buffer solution showed the best corrosion resistance followed by samples in $\mathrm{pH} \mathrm{2,1.5}$ and $7 \mathrm{NaCl}$ solutions, due to higher $\mathrm{RP}$ and lower Icorr at FP of potentiodynamic curves. Samples in $\mathrm{pH} 7 \mathrm{NaCl}$ showed poor corrosion resistance due to the presence of aggressive chloride ions in the solution. The weight and $\mathrm{pH}$ analysis after corrosion test in
Table 7 showed that poor corrosion resistance in $\mathrm{pH} 7$ $\mathrm{NaCl}$ solution had net loss in sample weight with increase in $\mathrm{pH}$ value of the corroded solution. However, samples with good corrosion resistance of $\mathrm{pH} 7$ buffer solution had net gain in sample weight and no change in $\mathrm{pH}$ value after corrosion. The net gain in sample weight shows that a passive layer probably formed.

The results of ICPMS $(\mu \mathrm{g} / \mathrm{L})$ and ICPOES $(\mathrm{mg} / \mathrm{L})$ test performed on electrolytes after corrosion test of HCWI in $\mathrm{pH} 7 \mathrm{NaCl}$ and buffer solutions are presented in Table 8 . There was significant dissolution of chromium and other elements such as manganese, silicon and vanadium at FP in $\mathrm{pH} 7 \mathrm{NaCl}$ solution rather than in $\mathrm{pH} 7$ buffer solution. Thus, these test results confirmed that corrosion was higher in $\mathrm{pH} 7 \mathrm{NaCl}$ than in $\mathrm{pH} 7$ buffer solution. The hardness test was done on carbide at $10 \mathrm{~g}$ load of alloy 2 sample after corrosion test in $\mathrm{pH} 7$ buffer solution shows that there was a significant drop in hardness from $1711 \mathrm{HV}$ to $65 \mathrm{HV}$ as shown in Table 9. This may be as a result of the formation of corrosion products on the surface of the existing carbide.

The back scattered electron image of alloy 1 sample of $\mathrm{pH} 1.5$ solution at FP in Fig. 12 shows that eutectic martensitic matrix dissolved completely leaving eutectic and primary carbides nearly intact. The secondary electron image of alloy 2 at pH 7 buffer solution in Fig. 13 shows that the carbides are hollow in shape and some cracks were

Table 6 Rest potential (Ecorr) and corrosion current (Icorr) at final potential

\begin{tabular}{lllll}
\hline & Alloy 1 (pH 1.5) & Alloy 2 (pH 2) & Alloy 1 (pH 7 NaCl) & Alloy 2 (pH 7 Buffer) \\
\hline Rest Potential (RP) (V) versus Ag/AgCl & -0.500 & -0.454 & -0.549 & -0.322 \\
Corrosion current (Icorr) (mA) & 32.3 & 21.9 & 406.9 & 12.9 \\
\hline
\end{tabular}

Table 7 Weight loss and $\mathrm{pH}$ analysis of Alloy 1 and 2 samples in $2 \mathrm{M} \mathrm{NaCl}$ and buffer solution before and after corrosion test

\begin{tabular}{lllllll}
\hline & \multicolumn{2}{l}{ Weight analysis } & & & \multicolumn{2}{l}{ PH analysis } \\
\cline { 2 - 3 } Samples & Before corrosion $(\mathrm{g})$ & After corrosion $(\mathrm{g})$ & Net gain/loss $(\mathrm{g})$ & & Before corrosion & After corrosion \\
\hline Alloy 1 $(\mathrm{NaCl})$ & 66.501 & 65.910 & -0.591 & 7.24 & 10.38 \\
Alloy 2 (Buffer) & 82.530 & 82.537 & +0.007 & 7 & 7 \\
\hline
\end{tabular}

Table 8 ICPMS and ICPOES analysis of $2 \mathrm{M} \mathrm{NaCl}$ and buffer solutions after corrosion test of Alloy1 and 2 samples

\begin{tabular}{|c|c|c|c|c|c|c|c|c|c|c|}
\hline Samples & $\begin{array}{l}\text { B }(\mu \mathrm{g} / \\
\mathrm{L})\end{array}$ & $\begin{array}{l}\mathrm{Cr}(\mu \mathrm{g} / \\
\mathrm{L})\end{array}$ & $\begin{array}{l}\mathrm{Fe}(\mu \mathrm{g} / \\
\mathrm{L})\end{array}$ & $\begin{array}{l}\mathrm{Fe}(\mathrm{mg} / \\
\mathrm{L})\end{array}$ & $\begin{array}{l}\mathrm{Mn}(\mu \mathrm{g} / \\
\mathrm{L})\end{array}$ & $\begin{array}{l}\text { Mo }(\mu \mathrm{g} / \\
\mathrm{L})\end{array}$ & $\begin{array}{l}\mathrm{Nb}(\mu \mathrm{g} / \\
\mathrm{L})\end{array}$ & $\begin{array}{l}\mathrm{Si}(\mu \mathrm{g} / \\
\mathrm{L})\end{array}$ & $\begin{array}{l}\mathrm{V}(\mu \mathrm{g} / \\
\mathrm{L})\end{array}$ & $\begin{array}{l}\mathrm{W}(\mu \mathrm{g} / \\
\mathrm{L})\end{array}$ \\
\hline $\begin{array}{l}\text { Alloy } 1(2 \mathrm{M} \mathrm{NaCl}, \\
\text { pH }=7)\end{array}$ & 3080 & 132,000 & - & 1370 & 6560 & - & - & 43.4 & 7290 & - \\
\hline Alloy $2($ Buffer, $\mathrm{pH}=7)$ & - & 4340 & 1450 & - & 24.2 & 387 & 15.8 & - & 261 & 80.5 \\
\hline
\end{tabular}


Table 9 Hardness of primary carbide of Alloy 2 sample before and after corrosion test in $\mathrm{pH} 7$ buffer solution

\begin{tabular}{lll}
\hline Sample & $\begin{array}{l}\text { Carbide (HV) before } \\
\text { corrosion }\end{array}$ & $\begin{array}{l}\text { Carbide (HV) after } \\
\text { corrosion }\end{array}$ \\
\hline $\begin{array}{c}\text { Alloy 2 } \\
\text { (Buffer) }\end{array}$ & 1711 & 65 \\
\hline
\end{tabular}

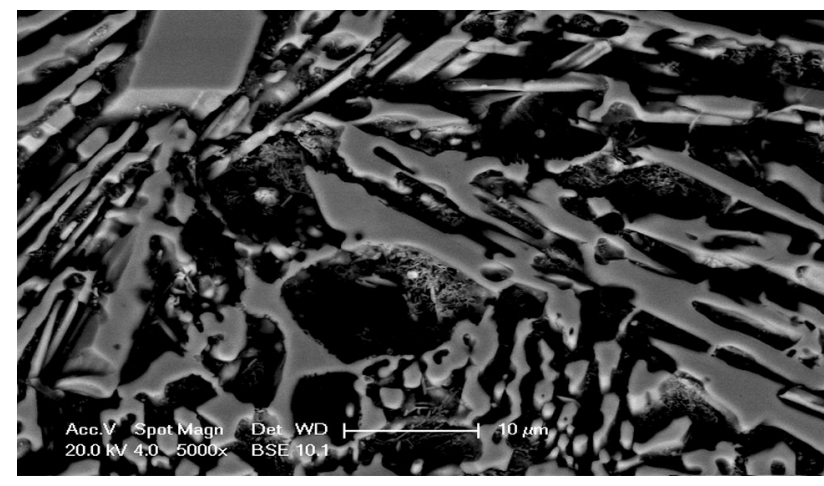

Fig. 12 Back scattered electron image of corrosion in eutectic martensite of Alloy 1 sample in $\mathrm{pH} 1.5$ solution

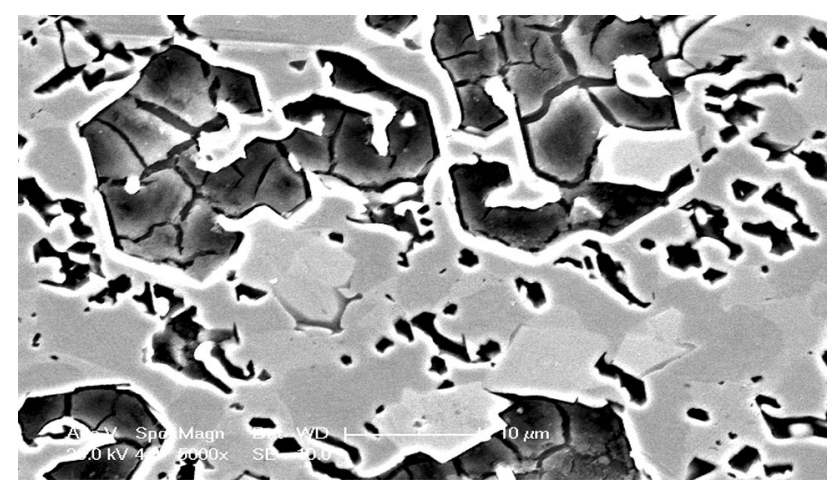

Fig. 13 Secondary electron image of corrosion in carbide of Alloy 2 sample in $\mathrm{pH} 7$ buffer solution

found. These images of Figs. 12, 13 show that after corrosion of eutectic martensitic matrix, the carbides seem to be unsupported, and corrosion of carbides makes HCWI samples not useful any longer to resist wear.

\subsubsection{Corrosion Analysis of Carbide and Eutectic Martensitic Matrix Samples}

After the eutectic martensitic matrix had dissolved in the potentiodynamic tests, the potential of the eutectic and primary carbides alone in the $\mathrm{pH} 1.5 \mathrm{H}_{2} \mathrm{SO}_{4}$ solution was measured for alloy 1 sample. For measuring these carbides potential, epoxy solution was placed on the surface of alloy 1 sample and this sample was repolished after the epoxy hardened [13]. Similarly, in order to measure the potential of eutectic martensitic matrix, the eutectic and primary
Table 10 Corrosion potential for carbide and matrix of Alloy 1 sample in $\mathrm{H}_{2} \mathrm{SO}_{4}$ solution of $\mathrm{pH} 1.5$

\begin{tabular}{ll}
\hline Sample (Alloy 1) & Corrosion potential (V) versus $\mathrm{Ag} / \mathrm{AgCl}$ \\
\hline Carbide & -0.370 \\
Matrix & -0.475 \\
\hline
\end{tabular}

carbides were dissolved in an alkaline solution. Again epoxy was applied to the sample surface and it was repolished. After preparing carbide and eutectic martensitic matrix sample, corrosion potential of the samples in $\mathrm{pH} 1.5$ $\mathrm{H}_{2} \mathrm{SO}_{4}$ solution is shown in Table 10. The carbide sample showed nobler potential than a eutectic martensitic matrix sample in $\mathrm{H}_{2} \mathrm{SO}_{4}$ solution of $\mathrm{pH}$ 1.5. Similarly, for $\mathrm{pH} 7$ $\mathrm{NaCl}$ solution, the eutectic martensitic matrix was not stable due to nobler potential of carbides. The carbides corroded in the $\mathrm{pH} 7$ buffer solution same as in the alkaline solution of $\mathrm{pH} 14$ [23, 41], whereas the eutectic austenite matrix sample showed nobler potential than a carbide sample as described in the literature [41] after extraction of carbide and eutectic austenite matrix sample in $\mathrm{pH} 14$ solution.

\section{Discussion}

\subsection{Galvanic Effect}

The results showed that corrosion of HCWI in $\mathrm{pH} 1.5$ and $\mathrm{pH} 7 \mathrm{NaCl}$ solutions occurs mainly in eutectic martensite. In $\mathrm{pH} 2$ solution, the corrosion occurs in eutectic carbides. In contrary, in $\mathrm{pH} 7$ buffer solution, the corrosion occurred in primary and eutectic carbides. The results of extraction of carbide and matrix sample showed that corrosion occurs mainly due to galvanic effect. Due to the potential difference, the dissolution of either eutectic martensitic or carbides depends upon the nature of electrolyte and $\mathrm{pH}$. So according to the nature of electrolyte, there would be a switch between the noble and active potentials. Other investigators found that in acid [1,8-12] and neutral [8, 14-19] solutions, corrosion was due to galvanic effect for HCWI materials. Zhang et al. [13] found similar galvanic effect by conducting experiments on carbide and matrix samples. The findings of Salasi et al. [23, 24] in neutral solution also showed that corrosion of either eutectic austenite matrix or carbides depended upon the formation of passive layer on the matrix. The passive layer of matrix led to the corrosion of carbides.

The corrosion trend of HCWI hardfacing deposits for different $\mathrm{pH}$ can be explained through the use of Pourbaix diagrams. Since the alloys have significant amounts of 
elements other than chromium, the superimposition of Pourbaix diagrams of other elements on chromium carbide Pourbaix diagrams will be useful in explaining the stability of these alloys in high $\mathrm{pH}$ solutions.

\subsection{Stability of Passive Formation of Matrix and Pourbaix Diagrams}

From the Pourbaix diagram of chromium carbide $\left(\mathrm{Cr}_{7} \mathrm{C}_{3}\right)$ as shown in Fig. 14, it can be seen for both acidic $\mathrm{pH}$ 1.5, 2 and neutral 7 solutions that the immune region is higher than for basic solution. At higher potentials for $\mathrm{pH} 1.5$ and 2, $\mathrm{Cr}_{7} \mathrm{C}_{3}$ forms $\mathrm{Cr}^{2+}$ followed by $\mathrm{Cr}^{3+}$ and $\mathrm{HCrO}_{4}{ }^{-}$. At higher potentials for $\mathrm{pH} 7, \mathrm{Cr}_{7} \mathrm{C}_{3}$ forms $\mathrm{Cr}_{2} \mathrm{O}_{3}$ followed by $\mathrm{CrO}_{4}{ }^{2-}$. The rest potentials measured for the hardfacing alloys at $\mathrm{pH} 1.5$ and 2 lie in the $\mathrm{Cr}^{3+}$ corrosion region, whereas $\mathrm{RP}$ measured at $\mathrm{pH} 7 \mathrm{NaCl}$ and buffer solutions lies in the $\mathrm{Cr}_{2} \mathrm{O}_{3}$ passive region. That is why due to $\mathrm{Cr}_{2} \mathrm{O}_{3}$ passive region, initial stage of alloy 2 potentiodynamic curve of $\mathrm{pH} 7$ buffer solution in Fig. 10 shows passive behaviour. For samples in solutions of $\mathrm{pH} 1.5$ and 2, the RP lies in $\mathrm{Cr}^{3+}$ corrosion region, initial stage of HCWI samples showed active behaviour as shown in Figs. 4 and 6. There is a sort of galvanic effect described in the previous section due to the presence of $\mathrm{Fe}$ in carbides and eutectic austenite. It would be useful to superimpose the Fe Pourbaix diagram [42] with Pourbaix diagram of $\mathrm{Cr}_{7} \mathrm{C}_{3}$ as shown in Fig. 14.

In the superimposed Pourbaix diagram of $\mathrm{Cr}_{7} \mathrm{C}_{3}$ with $\mathrm{Fe}$ as shown in Fig. 14 shows at pH 1.5 starts from RP till FP, the potentials lie in the corrosion regions of iron $\left(\mathrm{Fe}^{2+}\right.$, $\mathrm{Fe}^{3+}$ and $\mathrm{FeO}_{4}{ }^{2-}$ ) and chromium. As a result of corrosion region of iron and chromium as shown in Fig. 14, potentiodynamic curve of HCWI at pH 1.5 in Fig. 4 shows only active behaviour. Thus, the higher amount of $\mathrm{Fe}$ in eutectic martensitic matrix as given in Table 4 was not stable at $\mathrm{pH} 1.5$ forms active potential which leads to dissolution of eutectic martensitic matrix in preference to carbides as shown in Fig. 5. At pH 2, HCWI lies in the corrosion regions of chromium carbide, but due to the presence of passive region of $\mathrm{Fe}_{2} \mathrm{O}_{3}$ from points 1 to 2, the potentiodynamic curve shows slight passive behaviour. The formation of passive film $\mathrm{Fe}_{2} \mathrm{O}_{3}$ in eutectic austenite matrix attains nobler potential than carbides, which protects matrix from corrosion at $\mathrm{pH} 2$ as shown in Fig. 7. However, in $\mathrm{pH} 2$ solution corrosion in eutectic carbides rather than primary carbides occurred probably due to eutectic carbides generally being $\mathrm{Cr}_{23} \mathrm{C}_{6}$ carbides where the primary carbides are $\mathrm{Cr}_{7} \mathrm{C}_{3}[15,33-38]$. The stability of $\mathrm{Cr}_{23} \mathrm{C}_{6}$ eutectic carbides was less stable than $\mathrm{Cr}_{7} \mathrm{C}_{3}$ primary carbides as described in the literature [27] of Pourbaix diagrams of chromium carbides. The HCWI potentiodynamic curve of $\mathrm{pH} 7$ buffer solution in Fig. 10 shows passive behaviour from RP till point 1 , as their potentials are placed in the region of $\mathrm{Fe}_{2} \mathrm{O}_{3}$, as shown in Fig. 14 . However, the potentials after point 1 till FP in $\mathrm{pH} 7$ buffer solution show active behaviour. It is found that these potentials are located in the corrosion region of iron, as shown in Fig. 14. Thus, the high $\mathrm{Fe}$ eutectic austenite matrix attains noble potential in $\mathrm{pH} 7$ buffer solution, due to the formation of passive film on matrix which leads to dissolution of eutectic and primary carbides as shown in Fig. 11.

However, the results obtained for HCWI in $\mathrm{pH} 7 \mathrm{NaCl}$ solution show opposite behaviour compared to $\mathrm{pH} 7$ buffer solution. Although the potentials of $\mathrm{HCWI}$ at $\mathrm{pH} 7 \mathrm{NaCl}$
Fig. 14 Pourbaix diagram of $\mathrm{Cr}_{7} \mathrm{C}_{3}-\mathrm{Fe}$ in $\mathrm{pH} 1.5,2$ and 7 with anodic potentials of HCWI [27, 42]

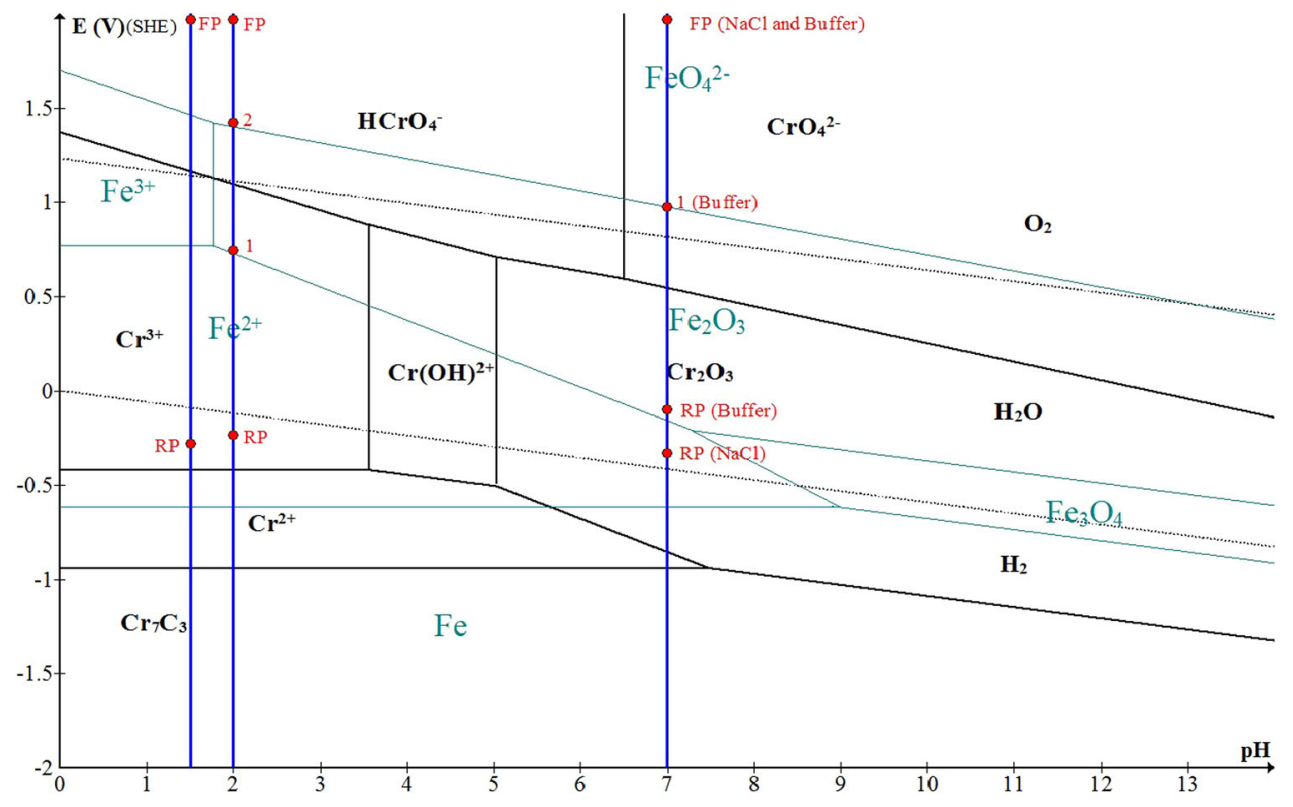


solution lie in the passive regions of $\mathrm{Cr}_{2} \mathrm{O}_{3}$ and $\mathrm{Fe}_{2} \mathrm{O}_{3}$, as shown in Fig. 14, the presence of aggressive chloride ions in the electrolyte did not allow the eutectic martensitic matrix to form passive layer. In that case, the eutectic martensitic matrix attains active potential and starts to corrode in preference to carbides, as shown in Fig. 9. Hence, the results of $\mathrm{pH} 7$ buffer and $\mathrm{NaCl}$ solutions show that corrosion of HCWI depends not only on $\mathrm{pH}$ but also on the nature of electrolyte. The study conducted by Salasi et al. [23] of cast HCWI in alkaline solution ( $\mathrm{pH}$ 12) with inclusion of chloride ions found that corrosion of eutectic austenite matrix happened mainly due to localised breakdown of passive layer. The same eutectic austenite matrix in alkaline solution was found to be relatively uncorroded resulting in the corrosion of carbides [23, 41].

The superimposed Pourbaix diagram of $\mathrm{Cr}_{7} \mathrm{C}_{3}$ with $\mathrm{NbC}$ in Fig. 15 shows that the immune region of $\mathrm{NbC}$ is larger than the $\mathrm{Cr}_{7} \mathrm{C}_{3}$ immune region. The $\mathrm{RP}$ of $\mathrm{pH} 2$ is located in the immune region, whereas $\mathrm{RP}$ for $\mathrm{pH} 7$ buffer solution is located in the passive region of $\mathrm{NbO}$. The higher potentials till FP of $\mathrm{pH} 2$ and $\mathrm{pH} 7$ buffer solution are placed in the passive region $\mathrm{NbO}$. This is the reason why in the alloy 2 microstructure of Fig. 7 and Fig. 11 after potentiodynamic tests in $\mathrm{pH} 2$ and $\mathrm{pH} 7$ buffer solutions showed $\mathrm{NbC}$ to be protected from severe corrosion even at FP. The study conducted by Arsova et al. [43] also confirmed that stable $\mathrm{NbO}$ passive film was detected through Raman spectroscopy in $\mathrm{H}_{2} \mathrm{SO}_{4}$ solution.

The development of superimposed Pourbaix diagram shows that formation of passive layer of eutectic austenitic or martensitic matrix plays a significant role in corrosion of HCWI hardfacing alloys. The findings of Kim et al. [44] on passive films of AISI 316 stainless steel in acidic $\mathrm{HCl}$ and $\mathrm{NaCl}$ solutions show that densities (thickness) of passive film are lower for $\mathrm{NaCl}$ solution than in acidic solution. The effect of chloride ions may affect the density of the passive film. The study conducted by Landolt et al. [45] for analysing the effects of chloride ion in passive film of $\mathrm{Fe}-$ $\mathrm{Cr}$ alloys showed that chloride ions were incorporated only at the time of growth of passive films. However, the chloride ions had no effect on the passive films which had already formed. The findings from Dobbelaar et al. [46] of $\mathrm{Fe}-\mathrm{Cr}$ alloys in $0.5 \mathrm{M} \mathrm{H}_{2} \mathrm{SO}_{4}$ showed that the contribution of iron in forming a passive layer at higher potential decreases the porosity of the passive film. The study [47] conducted for $\mathrm{Fe}-25 \mathrm{Cr}$ alloy in $0.1 \mathrm{M} \mathrm{H}_{2} \mathrm{SO}_{4}+0.4 \mathrm{M}$ $\mathrm{Na}_{2} \mathrm{SO}_{4}$ and $0.1 \mathrm{M} \mathrm{NaOH}$ solutions shows that there is mass loss in acidic solution. This shows that passive layer was not stable which leads to dissolution of alloys in the given solution.

The dissolution of either matrix or carbides in acid and neutral environments will have an effect of using HCWI hardfacing alloys for wear resistance. The matrix dissolution may lead to removal of carbides due to abrasive particles. Also the formation of passive layer $\mathrm{Cr}_{2} \mathrm{O}_{3}$ in chromium carbides can happen only when $\mathrm{Cr}_{7} \mathrm{C}_{3}$ dissociates to form $\mathrm{Cr}_{2} \mathrm{O}_{3}$ and carbon dioxide. However, the passive layer on either matrix or carbides, as seen through superimposed Pourbaix diagram of carbides [27, 28, 42], can be removed continuously through erosion-corrosion mechanism, which leads to severe material loss of HCWI hardfacing alloys. The only way to control the material loss due to erosion and corrosion by placing the HCWI hardfacing alloys in the immune region of the Pourbaix
Fig. 15 Pourbaix diagram of $\mathrm{Cr}_{7} \mathrm{C}_{3}-\mathrm{NbC}$ in $\mathrm{pH} 1.5,2$ and 7 with anodic potentials of HCWI $[27,28]$

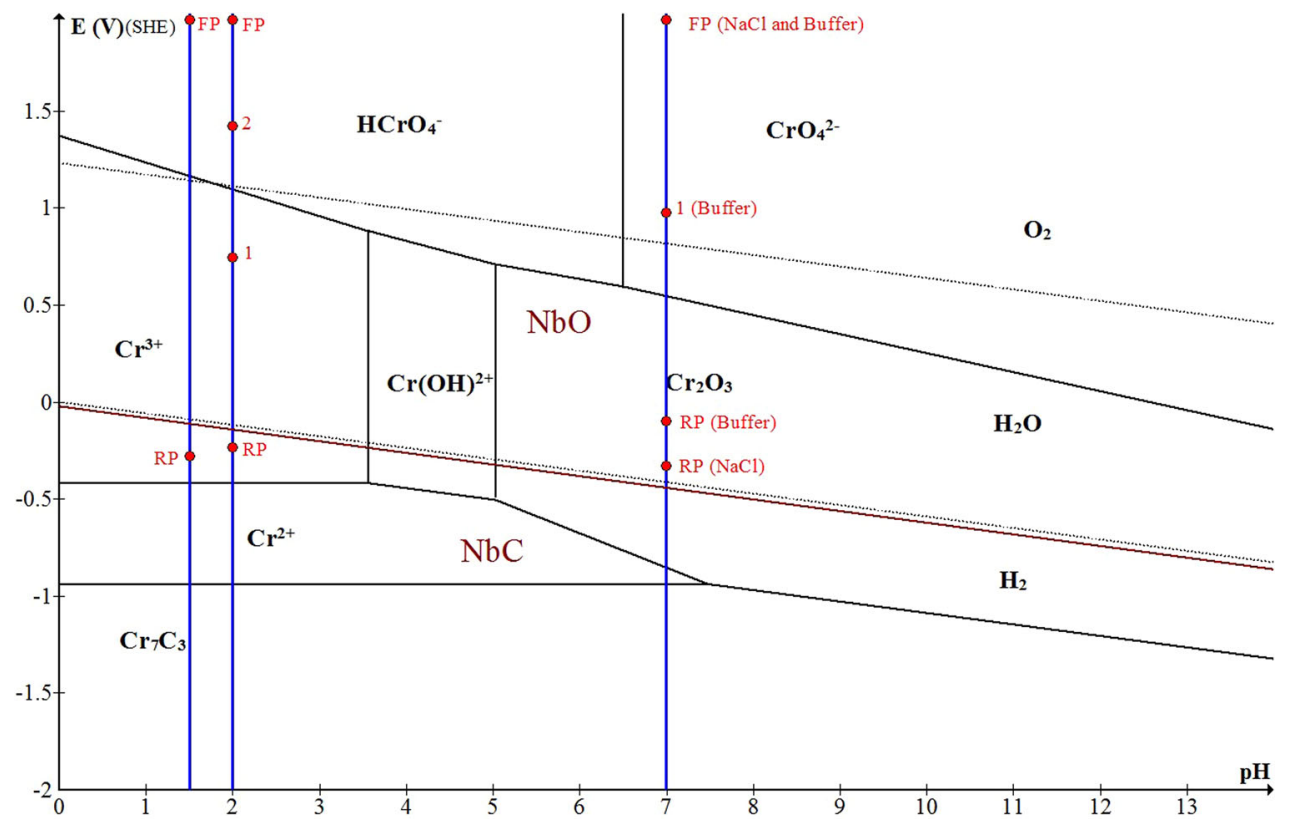


diagram. This can be done by cathodic protection of hardfacing alloys. Work is underway in this laboratory on conducting experiments for HCWI in different $\mathrm{pH}$ by placing at cathodic potentials and also introducing nitrogen during welding process. Nitrogen into the hardfacing alloys can form nitrides, carbo-nitrides or simply nitrogen as an alloying element. Nitrogen has been added in stainless steel to improve corrosion resistance $[48,49]$.

\section{Conclusions}

In this study, HCWI alloys were deposited on low carbon steel to investigate the behaviour of hardfacing overlays in acid and neutral solutions. The following conclusions were drawn from this study.

1. In acidic solution, at $\mathrm{pH} 1.5$, the preferential corrosion occurs on eutectic austenite or martensite matrix, whereas at $\mathrm{pH} 2$ the preferential corrosion happens on eutectic carbides for all the HCWI samples at higher potentials.

2. In neutral solutions, at $\mathrm{pH} 7$, the preferential corrosion occurs in matrix in $2 \mathrm{M} \mathrm{NaCl}$ solution, whereas the carbides get corroded with preference to matrix in the buffer solution.

3. The corrosion mechanism for the HCWI in both acid and neutral solution was galvanic. The uncorroded matrix or carbides attain noble potential, which act as a cathode, and the corroded matrix or carbides attain active potential, which act as an anode.

4. The addition of chloride ions in neutral solution alters the potential difference between carbides and matrix.

5. Pourbaix diagrams were very useful in explaining the corrosion trend of the hardfacing alloys.

\section{Compliance with Ethical Standards}

Conflict of Interest On behalf of all authors, Varmaa Marimuthu states that there is no conflict of interest.

\section{References}

1. Buchanan V, Shipway P, McCartney D (2007) Microstructure and abrasive wear behaviour of shielded metal arc welding hardfacings used in the sugarcane industry. Wear 263(1):99-110

2. Mishra (2006) Corrosion in the mining and mineral industry, corrosion: environment and industries. C orrosion, vol 13. ASM Handbook, Geauga, pp 1076-1082

3. Anderson R (2012) How to spec' screws barrels for running corrosive materials. Plast Technol 58(5):51-53

4. Popoola LT, Grema AS, Latinwo GK, Gutti B, Balogun AS (2013) Corrosion problems during oil and gas production and its mitigation. Int $\mathrm{J}$ Ind Chem 4(1):35
5. Fisher G, Wolfe T, Yarmuch M, Gerlich A, Mendez P (2012) The use of protective weld overlays in oil sands mining. Australas Weld J 57(2):12-14

6. Mathiesen T, Osvoll H, Mohseni P, Bjorneklett B (2015) Managing corrosion challenges with drilling risers and subsea equipment. Corrosion 2015 NACE International, Mar 15-19, Dallas

7. Rogers $\mathrm{P}$, Corrosive Degradation of hardfacing alloy in chlorinated seawater valve applications. Corrosion 2003, NACE International, Mar 16-20, San Diego

8. El-Aziz KA, Zohdy K, Saber D, Sallam H (2015) Wear and corrosion behavior of high-Cr white cast iron alloys in different corrosive media. J Bio Tri Corros 1(4):1-12

9. Tang XH, Chung R, Pang CJ, Li DY, Hinckley B, Dolman K (2011) Microstructure of high chromium cast irons and their resistances to wear and corrosion. Wear 271:1426-1431

10. Tang XH, Chung R, Li DY, Hinckley B, Dolman K (2009) Variations in microstructure of high chromium cast irons and resultant changes in resistance to wear, corrosion and corrosive wear. Wear 267:116-121

11. Tian HH, Taylor PA (2011) Corrosion study on high alloyed white cast irons in acidic and chloride containing solutions. Corrosion 2011. NACE International, Houstan

12. Zumelzu E, Goyos I, Cabezas C, Opitz O, Parada A (2002) Wear and corrosion behaviour of high-chromium (14-30\% Cr) cast iron alloys. J Mater Process Technol 128(1):250-255

13. Zhang A, Xing J, Fang L, Su J (2004) Inter-phase corrosion of chromium white cast irons in dynamic state. Wear 257(1):198-204

14. Azimi G, Shamanian M (2010) Effects of Sillicon content on the microstructure and corrosion behaviour of $\mathrm{Fe}-\mathrm{Cr}-\mathrm{C}$ hardfacing alloys. J Alloy Compd 505:598-603

15. Chang CM, Hsieh CC, Lin CM, Chen JH, Fan CM, Wu W (2010) Effect of carbon content on microstructure and corrosion behavior of hypereutectic $\mathrm{Fe}-\mathrm{Cr}-\mathrm{C}$ claddings. Mater Chem Phys 123(1):241-246

16. Sabet H, Mirdamadi S, Kheirandish S, Masoud G (2013) Effect of volume fraction of $(\mathrm{Cr}, \mathrm{Fe}) 7 \mathrm{C} 3$ carbides on corrosion resistant of the Fe-Cr-C hardfacing alloys. Assoc Metall Eng Serb 19(2):107-114

17. Neville A, Reza F, Chiovelli S, Revega T (2006) Characterization and corrosion behavior of high-chromium white cast irons. Metall Mater Trans A 37(8):2339-2347

18. Sain P, Sharma C, Bhargava A (2013) Microstructure aspects of a newly developed, low cost, corrosion-resistant white cast iron. Metall Mater Trans A 44(4):1665-1672

19. Salasi M (2012) Synergism between abrasion and corrosion. PhD Thesis, The University of Western Australia, Crawley

20. Menon R (2016) The development of hardfacing alloys for wear and corrosion resistance, http://victortechnologies.com/IM Uploads/Stoody/Dev_Corrosion_Abrasion_Resisitant_Overlay_ MenonCook_012415.pdf. Accessed 29 Jul 2016

21. Poolthong N, Nomura H, Takita M (2004) Effect of heat treatment on microstructure and properties of semi-solid chromium cast iron. Mater Trans 45(3):880-887

22. Wiengmoon A, Pearce J, Chairuangsri T (2011) Relationship between microstructure, hardness and corrosion resistance in $20 \mathrm{wt} \% \mathrm{Cr}, 27 \mathrm{wt} \% \mathrm{Cr}$ and $36 \mathrm{wt} \% \mathrm{Cr}$ high chromium cast irons. Mater Chem Phys 125(3):739-748

23. Salasi M, Stachowiak G, Stachowiak G (2011) Chloride effect on corrosion and corrosive wear of high-Cr cast irons in different $\mathrm{pH}$ solutions. In: Perth (ed) Proceedings of the 18th International Corrosion Congress, Australasian Corrosion Association (ACA), Melbourne, 20-24 Nov 2011, 1335-1346 
24. Salasi M, Stachowiak G, Stachowiak G (2011) Three-body tribocorrosion of high-chromium cast irons in neutral and alkaline environments. Wear 271(9):1385-1396

25. Foroulis Z (1980) Electrochemical behavior and corrosion of iron in aqueous sulfidic solution. Mater Corros 31(6):463-470

26. Mor E, Scotto V, Mollica A (1980) Contribution to the discussion on localized corrosion of stainless steels in natural sea water. Mater Corros 31(4):281-285

27. Marimuthu V, Dulac I, Kannoorpatti K (2016) Significance of Pourbaix diagrams to study the corrosion behaviour of hardfacing alloys based on chromium carbides at $298 \mathrm{~K}\left(25^{\circ} \mathrm{C}\right)$. J Biol Tribol Corros 2(3):1-7

28. Marimuthu V, Dulac I, Kannoorpatti K (2015) Thermodynamic analysis of corrosion of carbides of titanium, niobium and tungsten. In: Proceedings of the MISE Conference, Nov. Brisbane

29. AS/NZS 2576 (2005) welding consumables for build-up and wear resistance. Australian Standards, Sydney

30. AWRA (1979) AWRA technical note 4: hardfacing. Technical report, Australian Welding Research Association, Australia

31. Borle SD (2014) Microstructural characterization of chromium carbide overlays and a study of alternative welding processes for industrial wear applications. Thesis- Master of Science in Welding Engineering. University of Alberta, Edmonton Alberta

32. ASTM Standards (2011) G5-94 standard reference test method for making potentiostatic and potentiodynamic anodic polarization measurements. Annual book of ASTM standards, ASTM International, West Conshohocken, 3(2): 47-58

33. Chang CM, Chen LH, Lin CM, Chen JH, Fan CM, Wu W (2010) Microstructure and wear characteristics of hypereutectic $\mathrm{Fe}-\mathrm{Cr}-$ $\mathrm{C}$ cladding with various carbon contents. Surf Coat Technol 205(2):245-250

34. Chang CM, Chen YC, Wu W (2010) Microstructural and abrasive characteristics of high carbon $\mathrm{Fe}-\mathrm{Cr}-\mathrm{C}$ hardfacing alloy. Tribol Int 43(5):929-934

35. Chotěborský R, Hrabě P, Müller M, Savková J, Jirka M (2008) Abrasive wear of high chromium $\mathrm{Fe}-\mathrm{Cr}-\mathrm{C}$ hardfacing alloys. Res Agric Eng 54(4):192-198

36. Ma S, Xing J, He Y, Li Y, Huang Z, Liu G, Geng Q (2015) Microstructure and crystallography of $\mathrm{M}_{7} \mathrm{C}_{3}$ carbide in chromium cast iron. Mater Chem Phy 161:65-73

37. Lin CM, Chang CM, Chen JH, Hsieh CC, Wu W (2010) Microstructure and wear characteristics of high-carbon Cr-based alloy claddings formed by gas tungsten arc welding (GTAW). Surf Coat Technol 205(7):2590-2596

38. Lin CM, Chang CM, Chen JH, Hsieh CC, Wu W (2009) Microstructural evolution of hypoeutectic, near-eutectic, and hypereutectic high-carbon Cr-based hard-facing alloys. Metall Mater Trans A 40(5):1031-1038

39. Chotěborský R, Hrabě P, Müller M, Savková J, Jirka M, Navrátilová M (2009) Effect of abrasive particle size on abrasive wear of hardfacing alloys. Res Agric Eng 55(3):101-113

40. Yüksel N, Şahin S (2014) Wear behavior-hardness-microstructure relation of $\mathrm{Fe}-\mathrm{Cr}-\mathrm{C}$ and $\mathrm{Fe}-\mathrm{Cr}-\mathrm{C}-\mathrm{B}$ based hardfacing alloys. Mater Des 58:491-498

41. Marimuthu V, Kannoorpatti K (2016) Corrosion behaviour of high-chromium white iron hardfacing alloys in an alkaline solution. J Biol Tribol Corros 2(4):1-14

42. Verink E (2011) Simplified procedure for constructing Pourbaix diagrams. In: Revie RW (ed) Uhlig's corrosion handbook, vol 51(93). Wiley, New York, pp 111-124

43. Arsova I, Prusi A, Grčev T, Arsov L (2006) Electrochemical characterization of the passive films formed on niobium surfaces in $\mathrm{H} 2 \mathrm{SO} 4$ solutions. J Serb Chem Soc 71(2):177-187

44. Kim JJ, Young YM (2013) Study on the passive film of type 316 stainless steel. Int J Electrochem Sci 8(10):11847-11859

45. Hubschmid C, Mathieu H, Landolt D (1993) Comparative analysis by AES and XPS of passive films on Fe- $25 \mathrm{Cr}$-X model alloys formed in chloride and in sulfate solution," C. Hubschmid, H. J. Mathieu, and D. Landolt, Paper No. 401, 1993

46. Dobbelaar J, Herman E, De Wit J (1992) The corrosion behaviour of iron-chromium alloys in $0.5 \mathrm{M}$ sulphuric acid. Corros Sci 33(5):765-778

47. Schmutz P, Landolt D (1999) In-situ microgravimetric studies of passive alloys: potential sweep and potential step experiments with $\mathrm{Fe}-25 \mathrm{Cr}$ and $\mathrm{Fe}-17 \mathrm{Cr}-33 \mathrm{Mo}$ in acid and alkaline solution. Corros Sci 41(11):2143-2163

48. Smith RT (2015) Development of a nitrogen-modified stainlesssteel hardfacing alloy. PhD Thesis, The Ohio State University, Columbus

49. Sun LY, Li JS, Zhang LF, Yang SF, Chen YF (2011) Production of nitrogen-bearing stainless steel by injecting nitrogen gas. J Iron Steel Res Int 18(11):7-11 